César A. García-Franco

Bruce A. Harrington

David J. Lohse

\title{
On the rheology of ethylene-octene copolymers
}

\section{Rheol Acta (2005) 44:591-599. DOI: 10.1007/s00397-005-0441-8}

Published online: 12 October 2005

(C) Springer-Verlag 2005

The online version of the original article can be found at http://dx.doi.org/10.007/ s00397-005-0441-8

\section{A. García-Franco $(\bowtie)$}

B. A. Harrington

Baytown Technology and Engineering

Complex/West, ExxonMobil Chemical Co., 5200 Bayway Dr., Baytown, TX 77522,

USA

E-mail:

cesar.a.garcia-franco@exxonmobil.com

Tel: + 1-281-8342447

Fax: + 1-281-8341793

D. J. Lohse

Corporate Strategic Research Labs, ExxonMobil Research \& Engineering Co., 1545 Route 22 East, Annandale,

NJ 08801, USA
Unfortunately, the publisher failed to print the acknowledgment for this article. The missing acknowledgement for this article should have read:

\section{Acknowledgements}

The authors express their gratitude to ExxonMobil Chemical Company for permission to publish this work, and gratefully acknowledge the contributions of M. Amin, B. Brown, G. Capone, and H. Dong to this work. 